\title{
UPAYA MENINGKATKAN HASIL BELAJAR MATEMATIKA MATERI BANGUN DATAR DENGAN METODE TGT (TEAMS GAME TURNAMENT) PADA KELAS IV MI NW KARANG BARU TAHUN PELAJARAN 2019/2020
}

\author{
Nita Sunarya Herawati \\ STAI Darul Kamal NW Kembang Kerang, Jl. Parawisata Kembang Kerang NTB \\ sunarya.nsh@gmail.com
}

\begin{abstract}
Abstrak
Tujuan penelitian ini adalah untuk meningkatkan hasil belajar dan memenuhi target pencapaian KKM 80\% matematika mengenai materi bangun datar dengan menggunakan Metode Pembelajaran TGT (Teams Game Tournament) pada kelas IV MI NW Karang Baru, kecamatan Wanasaba, Kabupaten Lombok Timur, tahun ajaran 2019/2020. Penelitian ini adalah Penelitian Tindakan Kelas (PTK) dengan langkah perencanaan, tindakan, observasi dan refleksi yang dilaksanakan dengan dua siklus. Siklus I dilaksanakan pada tanggal 15 Mei 2020, dan Siklus II dilaksanakan pada tanggal 22 juni 2020. Berdasarkan hasil penelitian yang dilakukan di MI NW Karang Baru Kecamatan Wanasaba Timur Kabupaten Lombok Timur tahun ajaran 2019/2020, dapat disimpulkan bahwa Metode Pembelajaran TGT (Teams Game Tournament) dapat meningkatkan hasil belajar dan dapat memenuhi target pencapaian KKM 80\% matematika bangun datar pada siswa kelas IV. Hal ini dibuktikan dengan adanya peningkatan ketuntasan hasil belajar matematika pada setiap siklus dan adanya capaian presentase hasil belajar matematika yang secara klasikal sudah melampui batas capaian KKM. Peningkatan hasil belajar siswa dilihat dari peningkatan nilai rata-rata kelas dari Pra Siklus ke Siklus I yaitu 5,7 dengan nilai rata-rata Pra Siklus 69,9 dan Siklus I 75,6. Siklus I ke Siklus II terjadi peningkatan 4,9 dari nilai rata-rata 75,6 menjadi 80.5. Tercapaianya target pencapaian KKM terbukti pada hasil dari Siklus II dengan rincian; Siklus I siswa yang tuntas sebanyak 14 anak dengan presentase ketuntasan baru mencapai 66,7\%, kemudian pada Siklus II siswa yang tuntas sebanyak 18 anak dengan presentase ketuntasan sudah melampui batas pencapaian secara klasikal yaitu $85.7 \%$.
\end{abstract}

Kata kunci: Hasil Belajar, Metode Pembelajaran TGT (Teams Game Tournament).

\section{PENDAHULUAN}

Tujuan pembelajaran matematika secara umum adalah agar siswa mampu dan trampil menggunakan matematika. Selain itu juga, dengan pembelajaran matematika dapat memberikan tekanan penataran nalar dalam penerapan matematika dan mempersiapkan siswa agar sanggup menghadapi perubahan keadaan dan pola pikir dalam kehidupan dan dunia selalu berkembang.

Masih rendahnya hasil pembelajaran siswa dalam matematika merupakan indikasi bahwa tujuan yang ditentukan dalam kurikulum belum tercapai secara optimal. Oleh karena itu, berbagai upaya untuk meningkatkan hasil belajar siswa harus terus dilakukan. Upaya tersebut diperlukan motivasi belajar yang tinggi, semangat belajar yang besar dan rasa percaya diri yang tinggi. Upaya dalam menumbuhkan semangat pada siswa khususnya pelajaran matematika dengan memilih metode pembelajaran yang tepat sesuai materi yang akan disampaikan. Selain 
itu, siswa juga memerlukan alat bantu berupa media yang dapat memperjelas apa yang akan disampaikan dan menarik perhatian siswa sehingga lebih cepat memahami dan mengerti apa yang disampaikan oleh guru.

Menurut Wragg pembelajaran yang efektif adalah pembelajaran yang memudahkan siswa untuk mempelajari sesuatu yang bermanfaat, seperti fakta, ketrampilan, nilai, konsep dan bagaimana hidup serasi dengan sesama atau hasil belajar yang diinginkan. ${ }^{1}$ Pembelajaran yang kreatif, efektif dan menyenangkan akan menumbuhkan semangat siswa. Adanya semangat yang tinggi, guru akan lebih mudah dalam meningkatkan hasil belajar siswa.

Berdasarkan hasil observasi yang dilakukan pada tanggal 23 Januari 2020 yang bertempat di MI NW Karang Baru kelas IV bahwa hasil pembelajaran matematika masih rendah dibanding dengan mata pelajaran lainnya., Rendahnya hasil belajar ditandai dengan banyaknya siswa yang belum mencapai KKM yaitu 70. Diketahui dari 21 siswa kelas IV hanya 8 orang (38\%) yang mampu mencapai KKM memperoleh nilai $\geq 70$. Sedangkan sisanya 13 orang $(62 \%)$ nilainya masih di bawah dari KKM $\leq 70$. Persentase tersebut masih kurang dari tujuan yang diharapkan dalam pembelajaran matematika $\mathrm{MI}^{2}$.

Melihat beberapa permasalahan yang ada di MI NW Karang Baru, peneliti memberikan penawaran kerjasama dengan guru kelas IV yaitu penerapan metode TGT (Teams Game Turnament) dengan bantuan media gambar untuk meningkatkan hasil belajar matematika siswa. Fungsi media pembelajaran secara umum adalah suatu alat bantu yang digunakan oleh orang (guru) untuk menyampaikan pesan kepada siswanya. Salah satu bentuk pembelajaran kooperatif adalah TGT (Teams Games Tournament). Pembelajaran kooperatif TGT adalah salah satu tipe atau bentuk pembelajaran kooperatif yang mudah diterapkan melibatkan aktivitas seluruh siswa tanpa ada perbedaan status yang melibatkan peran siswa sebagai tutor sebaya dan mengandung unsur permainan. ${ }^{3}$

\section{METODE}

Penelitian ini adalah Penelitian Tindakan Kelas (PTK) dengan pendekatan metode kualitatif. Penelitian Tindakan Kelas merupakan suatu upaya untuk mencermati kegiatan belajar sekelompok siswa dengan memberikan sebuah tindakan (treatment) yang sengaja dimunculkan. ${ }^{4}$ Tujuan dari pelaksanaan PTK adalah memperbaiki dan meningkatkan kondisi-kondisi belajar

\footnotetext{
${ }^{1}$ Ahmad Susanto, Teori Belajar \& Pembelajaran di Sekolah Dasar,...., 188.

${ }^{2}$ Observasi Tanggal 23 Januari 2020 Di Kelas IV MI NW Karang Baru, Wanasaba, Lombok Timur

${ }^{3}$ Wawancara Tanggal 23 Januari 2020 Di Kelas IV MI NW Karang Baru, Wanasaba, Lombok Timur.

${ }^{4}$ Mulyasa, Praktik Penelitian Tindakan Kelas, 107.
} 
serta kualitas pembelajaran. ${ }^{5}$ Subjek dalam penelitian ini adalah siswa kelas IV MI NW Karang Baru, Kecamatan Wanasaba, terdiri dari 10 siswa laki-laki dan 11 siswa perempuan sehingga berjumlah 21 siswa sedangkan objek dalam penelitian ini adalah meningkatkan hasil belajar matematika materi bangun datar dengan metode TGT (Team Games Tournament) pada siswa kelas IV MI NW Karang Baru tahun 2019/2020.

Rencana tindakan penelitian terdiri dari beberapa tahapan dalam siklus-siklus tindakan yang terdiri dari empat tahap, (1) perencanaan, (2) pelaksanaan atau tindakan, (3) pengamatan atau observasi (4) refleksi:

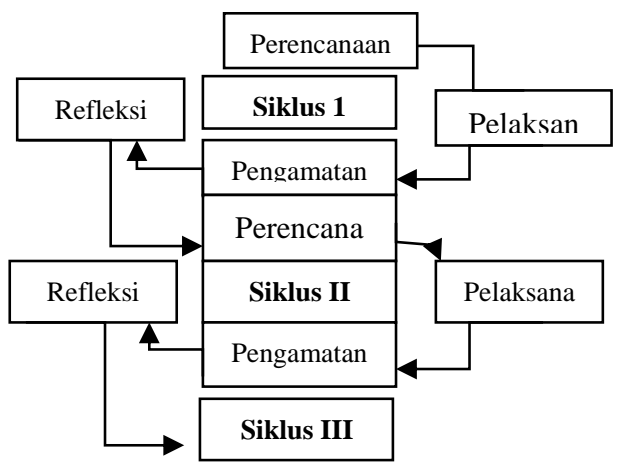

Siklus Penelitian Tindakan Kelas ( PTK ) Model Kurt Lewin ${ }^{6}$

Teknik pengumpulan data yang digunakan dalam penelitian ini adalah observasi,wawancara, tes dan dokumentasi. Sedangkan Instrumen pengumpulan data yag digunakan adalah lembar observasi, pedoman wawancara, soal tes, dan dokumentasi.

Analisis data pada penelitian ini dilakukan selama proses pembelajaran setelah data terkumpul, peneliti menganalisis, mereduksi, dan menyimpulkan data itu. Pengumpulan dilakukan setiap siklus penelitian tindakan kelas. Dengan adanya penyimpulan setiap siklus, peneliti akan dapat memahami proses tindakan yang dilakukan guru dalam pembelajaran.

Teknik analisis data yang digunakan dalam penelitian ini adalah analisis deskriptif kantitatif, yaitu menggambarkan data dengan menggunakan angka-angka. Teknik analisis data dalam penelitian ini untuk menguji hasil belajar matematika kelas IV MI NW Karang Baru dengan cara memberikan tes evaluasi individu pada setiap siklus. Analisa data kuantitatif digunakan untuk membandingkan hasil belajar sebelum dan sesudah penerapan metode pembelajaran TGT (Teams Game Tournament) yaitu pada pra siklus, siklus I, Siklus II dan seterusnya sampai mencapai KKM yang ditentukan. Untuk menghitung data-data yang

\footnotetext{
${ }^{5}$ Ibid, 11.

${ }^{6}$ Suharsimi Arikunto, Penelitian Tindakan Kelas, ( Jakarta: PT Bumi Aksara, 2009), 16.
} 
berupa angka dari hasil tes, peneliti akan menggunakan rumus statistika ukuran rata-rata kelas. Rata-rata kelas dapat dihitung dengan rumus. ${ }^{7}$

$$
\bar{x}=\frac{\sum \times}{\mathrm{N}}
$$

Keterangan:

$$
\begin{gathered}
\bar{x}=\text { Rerata nilai (Nilai rata-rata siswa) } \\
\begin{array}{c}
\sum \times=\text { Jumlah nilai mentah yang dimili subjek (Jumlah nilai siswa) } \\
\quad \mathrm{N}=\text { Banyaknya subjek yang memiliki nilai (Jumlah siswa) }
\end{array}
\end{gathered}
$$

Indikator keberhasilan dalam penelitian ini adalah meningkatnya rata-rata hasil belajar matematika siswa minimal $80 \%$ siswa telah mencapai standar nilai Kriteria Ketuntasan Minimal (KKM) dengan memperoleh nilai $\geq 70$ dengan skala 0-100 dengan menggunakan metode TGT (Teams Game Toumament). Untuk menghitung persentase ketuntasan belajar digunakan rumus sebagai berikut:

$$
K B=\frac{\mathrm{P}}{\mathrm{N}} \times 100 \%
$$

Keterangan:

$$
\begin{aligned}
& \mathrm{KB}=\text { Persentase ketuntasan belajar } \\
& \mathrm{P}=\text { Jumlah siswa yang memperoleh nilai } \geq 70 \\
& \mathrm{~N}=\text { Jumlah siswa }
\end{aligned}
$$

Jika $\mathrm{P} \geq 80 \%$, maka dikatakan tuntas secara klasikal dan jika $\mathrm{P} \leq 80 \%$, maka belajar dilakukan belum tuntas.

\section{HASIL}

Penelitian ini dilaksanakan pada siswa kelas IV MI NW Karang Baru pada bulan mei- juni 2020 mata pelajaran matematika materi bangun datar pada semester II tahun ajaran 2019/2020. Penelitian ini dilaksanakan dalam 2 siklus, pada setiap siklusnya terdiri dari 2 pertemuan yaitu: pertemuan 1 penerapan metode taem game tournament (TGT) dan pertemuan ke 2 menjawab soal test evaluasi individu. Penelitian ini menggunakan kelas darurat dalam pembelajaran yang jadwalnya disepakati oleh peneliti, kepala sekolah dan guru matematika kelas IV. Penelitian ini dilaksanakan dalam lingkungan sekolah disesuaikan dengen situasi dan kondisi yang ada.

\footnotetext{
${ }^{7}$ Suharsimi Arikunto, “Menejemen Penelitian”(Jakarta: Rineka Cipta, 2007) 284.
} 
Kondisi awal sebelum dilakukan penelitian tindakan kelas dapat dilihat dari kebiasaan belajar matematika di kelas, ini ditunjukkan dengan masih rendahnya kemampuan siswa dalam materi bangun datar. Kondisi awal ini digunakan sebagai acuan dalam melaksanakan penelitian tindakan kelas pada siswa kelas IV MI NW Karang Baru, Kecamatan Wanasaba.

Berdasarkan pengamatan terhadap siswa sebelum penelitian, menunjukkan bahwa masih rendahnya kemampuan siswa terhadap mata pelajaran matematika terutama pada materi bangun datar pada semester II. Kemampuan siswa dalam mengerjakan matematika dapat dilihat pada tabel berikut ini:

Tabel Hasil Belajar Matematika Siswa Kelas IV MI NW Karang Baru Pra Penelitian

\begin{tabular}{|c|l|c|c|c|}
\hline No & \multicolumn{1}{|c|}{ Nama Siswa } & $\begin{array}{c}\text { Jenis } \\
\text { Kelami } \\
\text { n }\end{array}$ & Nilai & KKM \\
\hline 1 & Moh. Nazir Halik & L & 66 & - \\
\hline 2 & Muh. Zainul Azmi & L & 76 & V \\
\hline 3 & Muhammad Harmaen & L & 66 & - \\
\hline 4 & Muhammad Maulana Syakuri & L & 76 & V \\
\hline 5 & Muhammad Nur Helwan & L & 66 & - \\
\hline 6 & Muhammad Ramdani & L & 68 & - \\
\hline 7 & Muzamil Ibadul Haer & L & 66 & - \\
\hline 8 & Nova Apandi & L & 66 & - \\
\hline 9 & Nur Laeli Alviani & P & 65 & - \\
\hline 10 & Rajibul Irgi Mukarrabin & L & 64 & - \\
\hline 11 & Radika Masri & L & 63 & - \\
\hline 12 & Raodatul Jannah & P & 66 & - \\
\hline 13 & Ridwanul Hafizin Sibang & L & 66 & - \\
\hline 14 & Rita Diana Putri & P & 82 & V \\
\hline 15 & Siti Kasyifa Aulia & P & 82 & P \\
\hline 16 & Siti Maulida & P & 76 & $\sqrt{ }$ \\
\hline 17 & Sri Mulyani & P & 76 & $\sqrt{ }$ \\
\hline 18 & Tiara Maulida Azzahra & P & 80 & $\sqrt{ }$ \\
\hline 19 & Ulya Maratus Shalihah & P & 66 & - \\
\hline 20 & Zahrani & 56 & - \\
\hline 21 & Ziadatun Naim & 1468 & 8 \\
\hline & & & 69,9 & $38 \%$ \\
\hline
\end{tabular}

\section{NW Karang Baru}

\section{Keterangan :}

\section{KKM :70}

Berdasarkan tabel tersebut dapat dijelaskan bahwa siswa kelas IV masih rendah dalam pelajaran matematika. Yakni dapat dilihat dari data nilai siswa, hanya 8 siswa (38\%) yang 
mendapatkan nilai yang mencapai KKM yaitu $\geq 70$ dengan nilai rata-rata siswa 69,9 dan 13 siswa $(62 \%)$ masih mendapatkan nilai di bawah KKM.

Data pengamatan ini digunakan sebagai dasar diterapkannya metode pembelajaran Teams Game Tournament (TGT) sebelum melakukan penelitian pada siswa kelas IV MI NW Karang Baru Kecamatan Wanasaba Kabupaten Lombok Timur.

Siklus I dilaksanakan pada tanggal 15 Mei 2020 di kelas IV dengan jumlah 21 siswa. Penelitian ini dilakukan dalam empat tahap yaitu perencanaan, pelaksanaan tindakan, observasi.

\section{Tabel Rekapitulasi Lembar Pengamatan Siswa}

\section{Siklus 1}

\begin{tabular}{|l|l|l|l|l|l|l|l|}
\hline \multirow{2}{*}{ No } & Fase & \multicolumn{5}{c|}{ Skor } & Jumlah \\
\cline { 3 - 8 } & & 0 & 1 & 2 & 3 & 4 & \\
\hline 1 & Kegiatan Awal & 0 & 0 & 3 & 1 & 0 & 9 \\
\hline 2 & Kegiatan Inti & 0 & 0 & 2 & 6 & 4 & 38 \\
\hline 3 & Kegiatan Akhir & 0 & 0 & 1 & 2 & 1 & 12 \\
\hline \multicolumn{3}{|c|}{ Jumlah } & \\
\hline \multicolumn{3}{|c|}{ Rata-Rata } & 2.95 \\
\hline
\end{tabular}

Skala kategori penskoran ${ }^{8}$.

\section{Skor minimal :0}

Skor maksimal :4

\section{Kategori Rata-Rata}

$$
\text { 0,0-0,8 : kurang sekali }
$$$$
\text { 0,9-1,6 : kurang }
$$$$
\text { 1,7-2,4 : cukup }
$$$$
\text { 2,5-3,2 : baik }
$$

3,3- 4,0 : baik sekali

Tabel Hasil Tes Evalusi Individu

Siklus I

\begin{tabular}{|c|c|c|c|c|c|}
\hline \multirow{2}{*}{$\begin{array}{c}\text { Jumlah } \\
\text { Siswa }\end{array}$} & Siklus I & \multirow{2}{*}{ Nilai } & \multirow{2}{*}{ KKM } & \multicolumn{2}{|c|}{ Keterangan } \\
\cline { 5 - 6 } & & & & Tuntas & $\begin{array}{c}\text { Belum } \\
\text { Tuntas }\end{array}$ \\
\hline \multirow{3}{*}{21} & Jumlah Nilai & 1587 & 14 & 14 & 7 \\
\cline { 2 - 6 } & Nilai Rata-Rata & $\mathbf{7 5 , 6}$ & & & \\
\cline { 2 - 6 } & Persentase & & $\mathbf{6 6 , 7 \%}$ & $\mathbf{6 6 , 7 \%}$ & $\mathbf{3 3 , 3 \%}$ \\
\hline
\end{tabular}

\section{Keterangan :}

KKM $: 70$

${ }^{8}$ Afroh L, Arnanda, "Peningkatan Hasil Belajar Matematika tentang Operasi Hitung Pembagian Melalui Metode Kooperatif Tipe Teams Game Tournament (TGT) Pada Siswa Kelas III Di SDN Candigaron 02 Kecamatan Sumowono Kabupaten Semarang Tahun Pelajaran 2014/2015”, (Skripsi. Salatiga: IAIN Salatiga Jurusan Tarbiyah PGMI, 2015), 56. 
Siklus II dilaksanakan pada tanggal 22 Juni 2020 di kelas IV dengan jumlah 21 siswa. Penelitian ini dilakukan dalam empat tahap yaitu perencanaan, pelaksanaan tindakan, observasi.

TabelRekapitulasi Lembar Pengamatan Siswa

Siklus II

\begin{tabular}{|l|l|l|l|l|l|l|l|l|}
\hline \multirow{2}{*}{ No } & \multicolumn{1}{|c|}{ Fase } & \multicolumn{5}{|c|}{ Skor umlah } \\
\cline { 3 - 8 } & & 0 & 1 & 2 & 3 & 4 & \\
\hline 1 & Kegiatan Awal & 0 & 0 & 0 & 4 & 0 & 12 \\
\hline 2 & Kegiatan Inti & 0 & 0 & 0 & 6 & 6 & 42 \\
\hline 3 & Kegiatan Akhir & 0 & 0 & 0 & 3 & 1 & 13 \\
\hline \multicolumn{7}{|c|}{ Jumlah } \\
\hline \multicolumn{3}{|c|}{ Rata-Rata } \\
\hline
\end{tabular}

Skala kategori penskoran?

Skor minimal :0

Skor maksimal :4

\section{Kategori Rata-Rata}

0,0-0,8 : kurang sekali

0,9-1,6 : kurang

$1,7-2,4$ : cukup

2,5-3,2 : baik

Tabel Hasil Tes Evalusi Akhir

Siklus II

\begin{tabular}{|c|c|c|c|c|c|}
\hline \multirow{2}{*}{ Nama Siswa } & Siklus II & \multirow{2}{*}{ Nilai } & \multirow{2}{*}{ KKM } & \multicolumn{2}{|c|}{ Keterangan } \\
\cline { 5 - 7 } & & & & Tuntas & $\begin{array}{c}\text { Belum } \\
\text { Tuntas }\end{array}$ \\
\hline \multirow{2}{*}{21} & Jumlah Nilai & 1690 & 18 & 18 & 3 \\
\cline { 3 - 7 } & Nilai Rata-Rata & $\mathbf{8 0 , 5}$ & & & $\mathbf{1 4 , 3 \%}$ \\
\cline { 2 - 7 } & Persentase & & $85,7 \%$ & $\mathbf{8 5 , 7 \%}$ & $\mathbf{1 4} \%$ \\
\hline
\end{tabular}

Keterangan :

KKM

$: 70$

\section{PEMBAHASAN}

Berdasarkan data-data yang diperoleh dalam penelitian matematika materi bangun datar, maka diketahui bahwa penggunaan metode pembelajaran Teams Game Tournament (TGT) pada

${ }^{9}$ Afroh L, Arnanda, "Peningkatan Hasil Belajar Matematika tentang Operasi Hitung Pembagian Melalui Metode Kooperatif Tipe Teams Game Tournament (TGT) Pada Siswa Kelas III Di SDN Candigaron 02 Kecamatan Sumowono Kabupaten Semarang Tahun Pelajaran 2014/2015”, (Skripsi. Salatiga: IAIN Salatiga Jurusan Tarbiyah PGMI, 2015), 56. 
pembelajaran matematika materi luas dan keliling jajargenjang dan segitiga dapat meningkatkan hasil belajar siswa. Melalui metode pembelajaran Teams Game Tournament (TGT) siswa dapat belajar dengan menggunakan kelompok-kelompok kecil beranggotakan 5-6 siswa secara beterogen. Penggunaan kelompok-kelompok ini membantu siswa dalam proses pembelajaran serta dapat menyelesaikan masalah yang diberikan oleh guru.

Proses pembelajaran matematika pada siswa bkelas IV melalui metode pembelajaran Teams Game Toumament (TGT) dapat meningkatkan hasil belajar siswa pada materi bangun datar. Berdasarkan hasil evaluasi dari Siklus I sampai Siklus II menunjukkan bahwa sudah banyak siswa yang mencapai indikator keberhasilan yakni:

- Secara individu

Siswa dapat mencapai skor $\geq 70$ pada materi bangun datar.

- Secara klasikal

Presentase sebanyak $>80 \%$ dari total siswa dalam satu kelas sudah mendapat nilai $\geq 70$.

Melalui sistem belajar dalam tim, siswa terbantu dalam memahami materi bangun datar, dapat menjawab soal dalam game, dan dapat mengerjakan soal evaluasi dengan baik serta menuntun siswa menuju keberhasilan dalam belajarnya. Setelah melakukan penelitian tindakan kelas mulai dari Siklus I sampai Siklus II dapat diperoleh data nilai matematika materi bangun datar melalui metode pembelajaran Teams Game Toumament (TGT).

Tabel Peningkatan Hasil Belajar Siswa Pra Siklus Sampai

Siklus II

\begin{tabular}{|c|c|c|c|r|}
\hline \multirow{2}{*}{ Kegiatan } & \multirow{2}{*}{$\begin{array}{c}\text { Nilai } \\
\text { rata-rata }\end{array}$} & \multirow{2}{*}{ Persentase } & \multicolumn{2}{|c|}{ Peningkatan yang didapatkan } \\
& 69,9 & $38 \%$ & Rata-Rata & Pesentase \\
\hline Pra Siklus & 75,6 & $66,7 \%$ & 5,7 & $28,7 \%$ \\
\hline Silus I & & & 4,9 & $19 \%$ \\
\hline Siklus II & 80,5 & $85,7 \%$ & & \\
\hline
\end{tabular}

Dari hasil nilai presentase ketuntasan diatas dapat dijelaskan bahwa pada Pra Siklus siswa yang tuntas sebanyak 38\%. Pada Siklus I meningkat menjadi 66,7\% siswa yang tuntas dengan kenaikan 28,7\% dari Pra Siklus. Pada Siklus II tingkat ketuntasan siswa yaitu 85,7\% dengan kenaikan presentase 19\% dari Siklus I. Dari hasil tersebut dapat disimpulkan bahwa pembelajaran matematika dengan menggunakan metode pembelajaran Teams Game Toumament (TGT), dari Pra Siklus sampai Siklus II siswa mengalami peningkatan yang cukup baik

\section{SIMPULAN DAN SARAN}


Berdasarkan hasil penelitian yang dilakukan di MI NW Karang Baru, Kecamatan Wanasaba, Kabupaten Lombok Timur, Tahun Ajaran 2019/2020, dapat disimpulkan bahwa metode pembelajaran Teams Game Tournament (TGT) dapat meningkatkan hasil belajar matematika materi bangun datar pada siswa kelas IV. Hal ini dibuktikan dengan adanya peningkatan ketuntasan hasil belajar matematika pada setiap siklus. Peningkatan hasil belajar siswa dilihat dari peningkatan nilai rata-rata kelas dari Pra Siklus ke Siklus I yaitu 5,7 dengan nilai rata-rata Pra Siklus 69,9 dan Siklus I 75,6. Siklus I ke Siklus II terjadi peningkatan 4,9 dari nilai rata-rata 75,6 menjadi 80,5 .

\section{REFERENSI}

Arikunto, Suharsimi. (2009). Penelitian Tindakan Kelas. Jakarta: PT Bumi Aksara . (2007). Menejemen Penelitian. Jakarta: PT Rineka Cipta.

Mulyasa. (2017). Praktik Penelitian Tindakan Kelas . Bandung: Rosda.

Susanto, Ahmad. (2013). Teori Belajar \& Pembelajaran di Sekolah Dasar. Jakarta:Kencana.

Afroh L, Arnanda.2013. Peningkatan Hasil Belajar Matematika tentang Operasi Hitung Pembagian Melalui Metode Kooperatif Tipe Teams Game Tournament (TGT) Pada Siswa Kelas III Di SDN Candigaron 02 Kecamatan Sumowono Kabupaten Semarang Tabun Pelajaran 2014/2015. Skripsi. Salatiga: IAIN Salatiga Jurusan Tarbiyah PGMI. 